\title{
GREEN SUPPLY CHAIN MANAGEMENT: MEDIASI DAYA SAING DAN KINERJA PERUSAHAAN MANUFAKTUR
}

\author{
Edy Jumady ${ }^{1}$, Yana Fajriah ${ }^{2)}$ \\ Program Studi Manajemen, Sekolah Tinggi Ilmu Ekonomi Makassar (STIEM) Bongaya \\ e-mail: ${ }^{1)}$ edy.jumady@stiem-bongaya.ac.id, ${ }^{2)}$ yanafajriah.stiem@gmail.com
}

\begin{abstract}
ABSTRAK
Pentingnya issu ramah lingkungan terkait aktivitas industri manufaktur di Kota Makassar saat ini menjadi perhatian khusus. Green supply chain management mengintegrasikan antara manajemen rantai pasokan dengan dengan manajemen lingkungan, sehingga penting dilakukan agar dapat mengurangi dampak lingkungan. Penelitian ini bertujuan untuk mengukur pengaruh green supply chain management terhadap daya saing, pengaruh green supply chain management terhadap kinerja perusahaan, pengaruh daya saing terhadap kinerja perusahaan, serta pengaruh green supply chain management terhadap kinerja perusahaan dengan daya saing sebagai variabel intervening. Penelitian ini menggunakan metode deskriptif dan untuk menguji hipotesis digunakan statistika inferensial yaitu Generalized Structured Component Analysis (GeSCA). Sampel penelitian ini berjumlah 75 responden manajer perusahaan manufaktur. Hasil penelitian menunjukkan: green supply chain management berpengaruh positif dan signifikan terhadap daya saing perusahaan, green supply chain management berpengaruh positif dan signifikan terhadap kinerja perusahaan, daya saing berpengaruh positif dan signifikan terhadap kinerja perusahaan, dan green supply chain management berpengaruh positif dan signifikan terhadap kinerja perusahaan dengan daya saing sebagai variabel intervening.
\end{abstract}

Kata kunci: Green supply chain management, Daya saing, Kinerja perusahaan, Generalized Structured Component Analysis.

\begin{abstract}
The importance of environmentally friendly issues related to manufacturing industry activities in Makassar is currently of particular concern. Green supply chain management integrates supply chain management with environmental management, so it is important to do so that it can reduce environmental impact. The objective of this study is to measure the effect of green supply chain management on competitiveness, effect of green supply chain management on company performance, effect of competitiveness on company performance, and effect of green supply chain management on company performance with competitiveness as intervening variable. This research used descriptive method and the hypothesis was tested by using inferential statistic, namely Generalized Structured Component Analysis (GeSCA). The research sample was 75 respondents of manufacture company managers. The research result denotes that green supply chain management has positive and significant effect on competitiveness, green supply chain management has positive and significant effect on company performance, competitiveness has positive and significant effect on company performance, and green supply chain management has positive and significant effect on company performance with competitiveness as the intervening variable.
\end{abstract}

Keywords: Green supply chain management, Competitiveness, Company Performance, Generalized Structured Component Analysis

\section{PENDAHULUAN}

Saat ini isu permasalahan lingkungan hidup telah menjadi sorotan masyarakat dunia yang menarik untuk dibahas. Pencemaran lingkungan di Indonesia yang semakin parah, merupakan dampak dari pengelolaan lingkungan yang tidak sesuai dengan yang ditetapkan. Beberapa perusahaan masih belum memikirkan mengenai dampak-dampak sosial yang timbul akibat dari praktik industri yang menggunakan teknologi canggih serta bahan-bahan kimia berbahaya, diantaranya adalah saat memperoleh bahan baku, proses produksi, dan hasil produksi yang efeknya menyebabkan pencemaran lingkungan seperti pencemaran udara, air, limbah dan sebagainya [1]. 
Supply chain sebagai kumpulan para pelaku usaha yang terlibat dalam serangkaian proses bisnis dalam suatu rantai pasokan [2]. Saat ini persaingan yang terjadi bukan lagi antara perusahaan dengan perusahaan lainnya, tetapi antara supply chain yang satu dengan supply chain yang lainnya [3]. Penerapan strategi rantai pasok yang terimplementasi dalam Green Supply Chain Management (GSCM) menggeser paradigma era industri baru yang menuntut peran industri dalam menjaga lingkungan dengan mengurangi atau menghilangkan polusi dan limbah, green supply chain management mewajibkan kegiatankegiatan industri untuk meningkatkan keseimbangan antara kinerja dengan isu lingkungan yang melahirkan isu baru seperti penghematan penggunaan energi, dan pengurangan polusi dalam usaha peningkatan strategi daya saing.

Supply chain management dapat mengintegrasikan praktek pengelolaan lingkungan ke dalam seluruh manajemen rantai pasokan dalam rangka mencapai green supply chain management dan mempertahankan keunggulan yang kompetitif dan juga untuk meningkatkan keuntungan bisnis dan tujuan pasar [4]. Perhatian ramah lingkungan diimplementasikan SCM dalam kinerja lingkungan yaitu Green Supply Chain Management (GSCM). Green Supply Chain Management (GSCM) menjadi salah satu strategi yang penting untuk mencapai pembangunan yang berkesinambungan bagi perusahaan [5].

Green Supply Chain Management merupakan sebuah inovasi dalam penerapan strategi rantai pasok yang didasarkan dalam konteks lingkungan yang mencakup aktivitasaktivitas seperti reduksi, recycle, reuse dan subsitusi material. GSCM merupakan pengintegrasian perspektif lingkungan ke dalam manajemen rantai pasok mencakup desain produk, pemilihan dan seleksi sumber bahan baku, proses manufaktur, pengiriman produk akhir kepada konsumen,serta pengelolaan produk setelah habis masa pakainya [6].

Dalam rangka mencapai GSCM, perusahaan harus mengikuti prinsip-prinsip dasar yang ditetapkan dalam klausul-klausul yang ada pada ISO 14001 yang mengelola tentang Sistem Manajemen Lingkungan. Beberapa fungsi operasional dan aktivitas-aktivitas dalam GSCM diantaranya: pengadaan hijau (green procurement), manufaktur hijau (green manufacturing), distribusi hijau (green distribution) Kegiatan dalam distribusi hijau yaitu kemasan hijau dan logistik hijau [6,7].

a) Pengadaan hijau (Green Procurement) Pengadaan hijau berkaitan dengan keadaan lingkungan pembelian yang terdiri dari keterlibatan dalam kegiatan pengurangan pembelian, pemakaian ulang dan daur ulang bahan pada proses pembelian.

b) Manufaktur hijau (Green Manufacturing) Manufaktur hijau merupakan proses produksi yang menggunakan input dengan dampak lingkungan yang rendah, sangat efisien dan menghasilkan sedikit bahkan tidak adanya limbah atau polusi.

c) Distribusi hijau (Green Distribution) Kegiatan dalam distribusi hijau yaitu kemasan hijau dan logistik hijau.

Upaya untuk menakar kinerja operasional perusahaan membutuhkan pendalaman tentang konsep manajemen operasional. Di era daya saing saat ini, manajemen operasional merupakan rangkaian aktivitas yang menghasilkan nilai dalam bentuk barang dan jasa dengan mengubah input menjadi output [8]. Ukuran kinerja atau parameter performance adalah suatu ukuran yang dibuat untuk mengukur tingkat keberhasilan atau kinerja fungsi, pekerjaan maupun kinerja industri secara umum. Dengan perkataan lain, ukuran kinerja dilakukan untuk mengetahui seberapa jauh suatu fungsi atau bagian tertentu dari perusahaan dan orang-orang yang bekerja didalamnya mencapai tujuan, baik tujuan umum maupun khusus yang ditugaskan kepada mereka.

Secara umum, kinerja didefinisikan sebagai tingkat keberhasilan di dalam suatu pekerjaan baik dari perorangan, kelompok, maupun organisasi/perusahaan. David Hunger dan Wheelen mendefinisikan kinerja adalah hasil akhir dari aktivitas. Di mana seleksi ukuran-ukuran untuk penaksiran kinerja tergantung kepada unit organisasi yang dinilai 
dan tujuan-tujuan yang dicapai [8]. Tujuan-tujuan yang telah ditetapkan sebelumnya dalam formulasi strategi sebagai bagian dari proses manajemen strategik (berhubungan dengan keuntungan, audit pemasaran, dan pengurangan biaya) harus di gunakan untuk mengukur kinerja perusahaan pada saat strategi tersebut diimplementasikan.

Penelitian ini selain menganalisis kinerja perusahaan juga menganalisis daya saing perusahaan, penelitian ini menggukan dua indikator pengukuran kinerja perusahaan, yaitu:

a) Kinerja Keuangan, kinerja umumnya dinilai biasanya dengan menggunakan pengukuran berbasis pada data keuangan [9]. Beberapa ahli menggunakan tingkat pengembalian atas penjualan (return on sales), profitabilitas, pertumbuhan penjualan, perbaikan produktivitas kerja, dan perbaikan biaya produksi untuk mengukur kinerja keuangan.

b) Kinerja Operasional, selain mengukur kinerja perusahaan berdasarkan kinerja keuangan, untuk menjelaskan kinerja perusahaan dengan baik digunakan juga pengukuran kinerja non-keuangan.

Perusahaan yang tidak mempunyai daya saing ditinggalkan oleh pasar, karena tidak memiliki daya saing berarti tidak memiliki keunggulan dan tidak unggul berarti tidak ada alasan bagi suatu perusahaan untuk tetap survive di dalam pasar persaingan untuk jangka panjang. Pandangan yang memiliki kesamaan dengan Lin \& Tsai dalam penciptaan keunggulan bersaing dikemukakan [10], bahwa jika suatu industri dapat menerapkan secara optimal flexibility, innovation, quality dan cost reductions, dengan penerapan secara optimal tersebut merupakan kunci kesuksesan industri dalam mendapatkan keunggulan bersaing.

Keunggulan bersaing merupakan kemampuan perusahaan untuk menciptakan dan mempertahankan superioritasnya terhadap para pesaing-pesaingnya dalam persaingan pasar. Berdasarkan fenomena yang terjadi di negara-negara maju, ternyata kunci dari peningkatan kinerja perusahaan terletak pada kemampuan perusahaan dalam bekerjasama dengan mitra bisnisnya.

Dimensi daya saing yang dimaksud dapat dikelompokkan ke dalam empat dimensi utama atau dimensi prioritas dalam persaingan operasi [11] yaitu; (1) Biaya (cost), (2) Kualitas (Quality), (3) Fleksibilitas (flexibility), dan (4) Inovasi (Innovation). Ke empat dimensi daya saing tersebut membentuk daya saing perusahaan dalam pasar yang kompetitif. Pengukuran daya saing mengacu pada pengukuran yang dikembangkan oleh Han et al. dalam [11], adalah sebagai berikut:

a) Efisiensi biaya merupakan tanggapan manajer terhadap pekerjaan untuk meningkatkan produkstivitas diikuti usaha untuk mencapai hasil dengan cacat seminim mungkin.

b) Kualitas merupakan tanggapan manajer terhadap kualitas produk perusahaan dibandingkan dengan kualitas pesaing lainnya.

c) Tingkat Fleksibilitas merupakan tanggapan manajer terhadap sikap antisipatif terhadap perubahan lingkungan yang diselaraskan dengan teknologi proses yang dapat dimodifikasi sehingga sesuai dengan tuntutan pasar.

d) Inovasi produk merupakan tanggapan manajer terhadap produk perusahaan yang lebih inovatif jika dibandingkan dengan pesaing lainnya.

Menurut Porter dalam [12] Penjabaran dari keempat indikator daya saing tersebut adalah: low cost, quality, delivery performance, flexibility. Pengukuran variabel keunggulan bersaing dalam penelitian ini mengembangkan pengukuran daya saing [13] yang mengukur keunggulan bersaing perusahaan dengan menggunakan indikator; harga, kualitas, delivery dependability, inovasi produk, dan time to market .

Pentingnya issu lingkungan terkait aktivitas industry manufaktur di era globalisasi saat ini menjadi menarik untuk diteliti lebih mendalam khususnya perusahaan manufaktur di Kota Makassar karena masih ada beberapa perusahaan yang mengabaikan green supply chain seperti belum optimalnya perusahaan mengolah limbah hasil produksi, pemanfaatan 
bahan baku (material) serta polusi produksi yang masih terjadi saat ini. Hal ini menjadi perhatian seluruh unsur yang terlibat mulai dari pemerintah, perusahaan sampai pada stakeholder dan konsumen dalam proses aliran material dan barang. Berdasarkan hasil PROPER pada periode penilaian tahun 2018 diikuti oleh perusahaan manufaktur di kota Makassar, tidak ada perusahaan manufaktur yang beroperasi di makassar dengan peringkat hijau, 10 perusahaan peringkat biru, 8 perusahaan kategori merah dan ada 1 perusahaan yang masuk kategori peringkat hitam yaitu PT. Barawaja. Hal ini menandakan bahwa masih minimnya kesadaran industri manufaktur yang memperhatikan lingkungan dalam proses produksinya (Kepmen Lingkungan Hidup dan Kehutanan RI Thn 2018).

Green supply chain management menintegrasikan antara manajemen rantai pasokan ndengan dengan manajemen lingkungan, sehingga penting dilakukan industri manufaktur karena dapat mengurangi dampak lingkungan dan dapat menciptakan daya saing dan kinerja yang tinggi. Keunggulan bersaing tercipta dan dapat dipertahankan oleh sebuah perusahaan yang mampu melakukan penyempurnaan secara berkesinambungan untuk menghasilkan nilai pelanggan yang terbaik melalui, biaya rendah (low cost), kualitas tinggi (high quality), dan novasi yang berkesimabungan (innovativeness).

Penelitian ini menguji hipotesis mengenai hubungan dan pengaruh antara Green supply chain management terhadap kinerja perusahaan dan daya saing sebagai variabel intervening. Hipotesis yang di uji yaitu: pertama, green supply chain management berpengaruh signifikan terhadap kinerja perusahaan. Kedua, green supply chain management berpengaruh signifikan terhadap daya saing perusahaan. Ketiga, daya saing berpengaruh signifikan terhadap kinerja. Dan keempat, green supply chain management berpengaruh signifikan terhadap daya saing dan kinerja perusahaan.

\section{METODE PENELITIAN}

Desain penelitian ini menggunakan pendekatan explanatory research dengan pengumpulan data dilakukan sekaligus dalam satu tahap (one short study). Penelitian explanatory research dimaksudkan untuk menjelaskan hubungan kasual antar variabel melalui pengujian hipotesis.

Populasi penelitian ini adalah seluruh perusahaan manufaktur yang tergolong dalam kategori industri manufaktur skala besar dan sedang yang beroperasi di Kota Makassar sebanyak 128 perusahaan dengan sampel 75 responden.

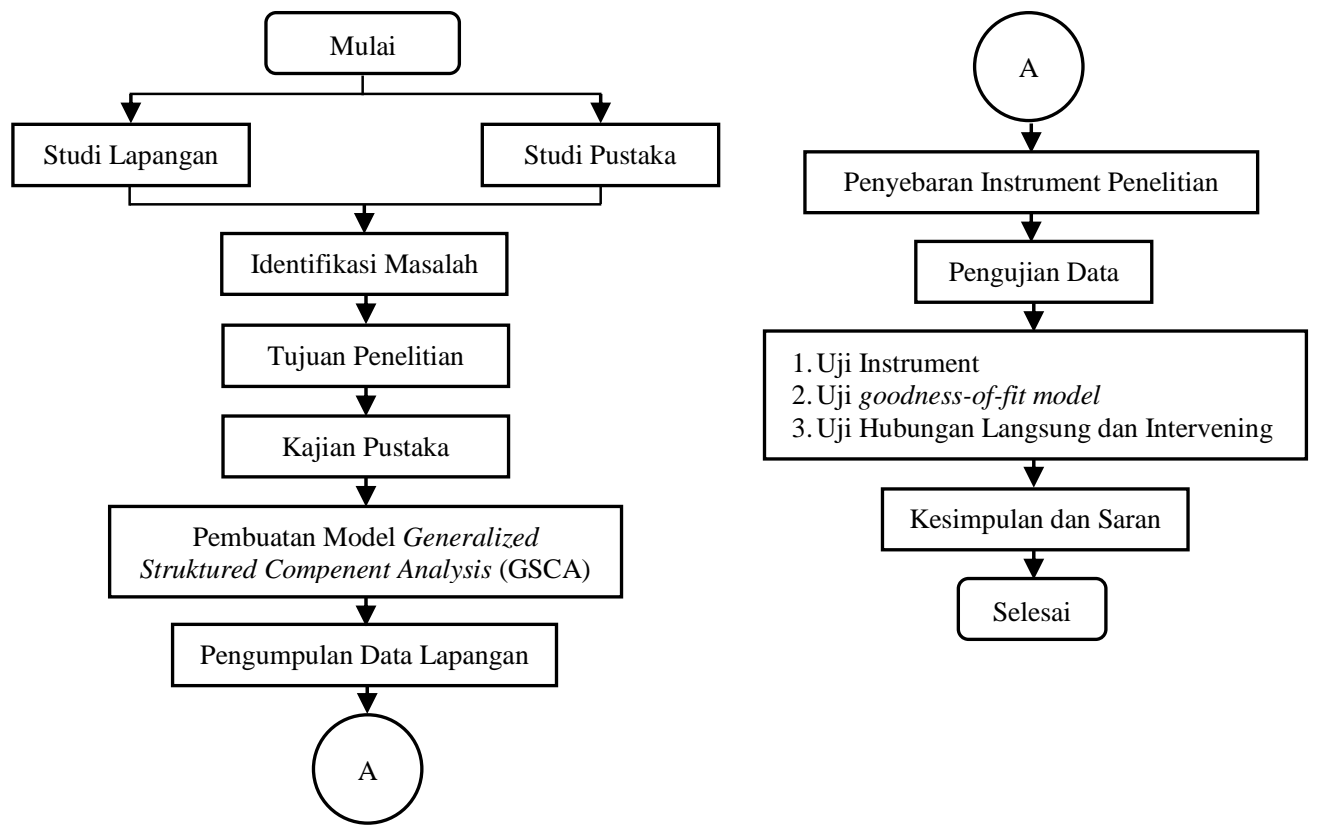

Gambar 1. Diagram Alir Penelitian 
Penelitian ini dimulai dengan melakukan studi lapangan dan studi pustaka agar dapat dilakukan identifikasi masalah. Setelah masalah teridentifikasi, selanjutnya dilakukan penetapan tujuan penelitian. Selanjutnya dilakukan kajian pustaka dari beberapa literatur dan penelitian terdahulu, selanjutnya pengumpulan dan pengolahan data dengan menggunakan metode Generalized Struktured Compenent Analysis (GSCA).

Metode pengumpulan data penelitian ini adalah:

a. Survei, dilakukan dengan menyebar angket kepada para direktur dan manajer pada setiap perusahaan manufaktur di Makassar. Angket yang dibuat bersifat tertutup.

b. Wawancara Mendalam (in-depth interview), metode dalam pengumpulan data dengan menggunakan teknik wawancara mendalam (in-depth interview).

Setelah semua data yang dibutuhkan telah terkumpul, selanjutnya dilakukan pengolahan data dengan tahapan sebagai berikut:

\section{Uji Instrument}

Untuk menguji kuesioner sebagai instrumen penelitian maka digunakan uji validitas (test of validity) dan uji reliabilitas (test of reliability). Uji Validitas Instrumen (Test of Validity), Instrument dapat dikatakan valid apabila mampu mengukur dan dapat mengungkapkan data dan variabel-variabel yang ditelit secara konsistens. Kriteria pengujian yang digunakan pada instrumen yang dikatakan valid jika nilai $r \geq 0,30$ dan nilai signifikansi korelasi $\leq$ dari $95 \%$ atau $\alpha=0,05$ [14].

Uji Reabilitas Instrumen (Test of Reability) adalah ukuran mengenai konsistensi internal dari indikator-indikator sebuah konstruk yang menunjukkan derajat sampai dimana masing-masing indikator variabel mengidentifikasi sebuah factor laten yang umum. Instrumen dianggap telah memiliki tingkat keandalan yang dapat diterima, jika nilai koefisien reabilitas yang terukur adalah $\geq 60$ [14].

\section{Teknik Analisis Data \& Uji Hipotesis}

Teknik analisis data yang digunakan dalam penelitian ini yaitu analisis deskripsi dan statistika inferensial yaitu Generalized Struktured Compenent Analysis (GSCA). Tujuannya adalah menggantikan faktor dengan kombinasi linear dari indikator (variabel manifes) dalam SEM [15]. Pendekatan analisis ini mengunakan metode kuadrat terkecil (least square) di dalam proses pendugaan parameter. Generalized Struktured Compenent Analysis (GSCA) adalah metode SEM berbasis komponen, sangat penting dan dapat dpergunakan untuk perhitungan skor dan dapat juga diterapkan pada sampel yang sangat kecil. Masalah singularitas dan multikolinearitas sering menjadi kendala yang sangat serius dalam analisis model structural menggunaka SEM berbasis kovarian [16].

Generalized Struktured Compenent Analysis (GSCA) memperbolehkan terjadinya multikonearitas, yaitu terjadi korelasi yang kuat antara variabel eksogen [15]. Alasan-alasan yang melatar belakangi pemilihan metode GSCA dalam penelitian ini sebagai berikut:

1. Model yang terbentuk pada kerangka konseptual penelitian ini, terlihat ada hubungan kausal berjenjang yaitu implementasi Green SCM mempengaruhi keunggulan bersaing selanjutnya mempengaruhi kinerja perusahaan. Dengan banyaknya hubungan serta berjenjang, maka permasalahan dan tujuan yang ingin dicapai hanya dapat diselesaikan dengan bantuan model berbentuk structural.

2. GSCA merupakan alat analisis yang cocok untuk melakukan simulasi pengembangan model dengan criteria pemilihan model yang tepat dengan menggunakan goodnessof fit (AFIT) yang terbesar.

3. Studi ini menggunakan variabel laten yang diukur melalui indikator. GSCA cocok digunakan untuk mengkorfimasi unidensionalitas dari berbagai indikator variabel laten baik indikator bersifat refleksi dan formatif. 
4. GSCA merupakan metode analasis yang power full yang tidak didasarkan banyak asumsi dan memungkinkan dilakukan analiss serangkaian dari beberapa variabel laten secara simultan sehingga memberikan efesiensi secara statistik.

5. Metode GSCA lebih mudah untuk dioperasikan dan spesifikasi model indikator refleksif dan formatif. Hal ini dikarenakan pada GSCA tidak memerlukan asumsi distribusi tertentu dan tidak memerlukan adanya modifikasi indeks.

6. Unit analisis penelitian ini adalah perusahaan manufaktur berskala besar dan sedang yang menerapkan Green Supply Chain Management di Kawasan Industri Makassar yang jumlahnya relatif kecil yaitu 75 perusahaan. Sehingga pendekatan analisis GSCA tepet untuk menggeneralisasi dari sampel yang sangat kecil.

Merujuk pada alasan-alasan pemilihan model GSCA, peneliti menyadari bahwa dalam penggunaan metode ini ada beberapa asumsi yang mendasari dalam penggunaanya. Asumsi GSCA hanya berkaitan ddengan pemodelan structural, dan tidak terkait dengan pengujian hipotesis yaitu: (1) hubungan antar variabel laten adalah linear dan aditif, pengujian dapat dilakukan dengan software SPSS melalui pendekatan Ramsey test/curve fit, dan (2) ukuran sampel dalam GSCA berdasar pada resampling (bootstrapping) tidak memerlukan sampel besar dan bisa teknik sampling non-probabbality.

Sesuai dengan kerangka konsep pemikiran, maka model yang dibangun adalah:

$\mathrm{Y}_{1}=f(\mathrm{X})$

$\mathrm{Y}_{2}=f\left(\mathrm{X}, \mathrm{Y}_{1}\right)$

Persamaan matemetis:

Sehingga:

$$
\mathrm{Y}_{1}=f(\mathrm{X})
$$

$\mathrm{Y}_{1}=\alpha_{0}+\alpha_{1} \mathrm{X}+\varepsilon$

$\mathrm{Y}_{2}=f\left(\mathrm{X}, \mathrm{Y}_{1}\right)$

Sehingga:

$$
\mathrm{Y}_{2}=\beta_{0}+\beta_{1} \mathrm{X}+\beta_{2} \mathrm{Y}_{1}+\varepsilon
$$

Pengujian hipotesis dalam riset ini bertujuan untuk menjawab apakah hipotesis yang diajukan diterima atau ditolak. Pengujian dilakukan dengan titik kritis (CR); p-value $\leq 0,05$ $(\alpha=0,05)$ artinya yaraf signifikasi estimasi parameter dalam pengujian hipotesis ditetapkan sebesar $95 \%$ atau $\alpha=0,05$.

\section{HASIL DAN PEMBAHASAN}

Tabel 1. Deskripsi Variabel

\begin{tabular}{l|l}
\hline Variabel & Rerata \\
\hline Green Supply Chains Management & 4,05 \\
Kinerja Perusahaan & 4,14 \\
Daya Saing & 4,34 \\
\hline
\end{tabular}

Sumber: Data Diolah

Tabel 1 menunjukkan bahwa tanggapan manajer terhadap keinginan manajer untuk pengadaan hijau (Green Procurement) telah diperlihatkan dengan baik oleh manajer dibuktikan dengan tingkat rerata sebesar 4,05.

Rerata tanggapan manajer terhadap daya saing sebesar 4,34 (berada pada kategori tinggi), sehingga dapat dijelaskan bahwa pada dasarnya perusahaan tempat dimana para manajer bekerja memiliki daya saing untuk menciptakan posisi bertahan di atas pesaingnya. 
Indikator variabel kinerja perusahaan menunjukkan bahwa mayoritas manajer setuju dengan nilai skor rata-rata 4,14. Sehingga dapat dinyatakan bahwa dalam pelaksanaannya ke-dua indikator variabel pengukuran variabel kinerja perusahaan telah dilaksanakan dengan baik, artinya bahwa secara umum manajer berkeinginan untuk meningkatkan kinerja perusahaan ke arah yang tinggi.

Kinerja keuangan dan kinerja operasional secara bersama-sama memberikan kontribusi yang besar terhadap peningkatan kinerja keuangan ke arah yang tinggi. Artinya bahwa manajer meyakini bahwa perusahaan memiliki kemampuan untuk mencapai tingkat pengembalian terhadap penjualan (return on sales) yang telah ditargetkan, keuntungan (profit) yang telah ditargetkan, tingkat pertumbuhan penjualan yang telah ditargetkan, tingkat produktivitas yang telah ditargetkan dan menggunakan biaya produksi yang telah ditargetkan atau bahkan lebih rendah sebagai refleksi dari kinerja keuangan perusahaan yang tinggi.

Model yang diuji dalam penelitian ini dikatakan fit apabila didukung oleh data empiris. GSCA memberikan ukuran goodness-of-fit yang terdiri dari fit model structural dan overall model yang dapat dilihat dari nilai FIT, AFIT, GFI (Unweighted least-squares) dan SRMR (Standardized root mean square residual). Hasil komputasi data penelitian ini dengan metode GSCA diperoleh model fit, yang dapat disajikan pada Tabel berikut.

Tabel 2. Evaluasi Goodness-of-fit Model Struktural dan Overall Model GSCA

\begin{tabular}{ll}
\hline Model Fit & \\
\hline FIT & 0,733 \\
AFIT & 0,720 \\
GFI & 0,990 \\
SRMR & 0,087 \\
NPAR & 89 \\
\hline \multicolumn{2}{l}{ Sumber: Hasil olahan GSCA }
\end{tabular}

Dari hasil output GSCA pada Tabel 2 evaluasi goodness-of-fit model struktural dan overall model penelitian ini, dapat diuraikan sebagai berikut:

1. Hasil output GSCA diperoleh nilai FIT sebesar 0,733 artinya bahwa model yang berbentuk dalam studi ini dapat menjelaskan semua variabel yang dianalisis sebesar $73,30 \%$. Keragaman variabel implementasi green supply chain, daya saing, dan kinerja perusahaan dapat dijelaskan oleh model sebesar 73,30\% dan sisanya 26,70\% dijelaskan oleh variabel lain di luar model penelitian. Dapat disimpulkan bahwa dari nilai FIT yang diperoleh model penelitian ini dapat dikatakan memiliki akurasi atau ketepatan model yang baik karena nilainya lebih besar dari $60 \%$.

2. AFIT sebesar 0,720 adalah adjusted dari FIT yang hampir mendekati dengan nilai FIT. Namun karena variabel yang mempengaruhi kinerja operasional dalam studi ini tidak hanya satu melainkan empat variabel yaitu: implementasi green supply chain, daya saing, dan kinerja perusahaan, sehingga lebih baik jika interpretasi ketepatan model menggunakan FIT yang sudah terkoreksi atau AFIT (Adjusted FIT). Jika dilihat dari nilai AFIT, keragaman variabel implementasi green supply chain, daya saing, dan kinerja perusahaan dapat dijelaskan oleh model penelitian ini sebesar 72,00\% dan sisanya $28,00 \%$ dijelaskan oleh variabel lain. Artinya, nilai AFIT yang diperoleh dapat dikatakan model yang terbentuk memiliki akurasi atau ketepatan model yang baik karena nilainya $>60 \%$.

3. GFI dan SRMR, keduanya sebanding dengan perbedaan antara kovarian sampel dan kovarian yang diproduksi oleh pendugaan parameter GSCA. Hasil analisis data terlihat nilai GFI sebesar 0,990 > cut-off poin 0,90 maka model yang terbentuk dapat dikatakan 
sudah sesuai atau baik. Namun nilai SRMR sebesar $0,087<0,1$ dapat dikatakan Good fit (model sesuai). Hal ini dimungkinkan terjadi pada penelitian ini masih dapat ditolerir karena nilai SRMR mendekati nol.

4. Nilai NPAR sebesar 89 menunjukkan jumlah parameter bebas yang termasuk koefisien loading (c), koefisien bobot (w), dan koefisien jalur (b) penelitian ini.

Berdasarkan goodness-of-fit model struktural dan model keseluruhan (overall model) dengan uji FIT, AFIT, GFI, dan SRMR dapat disimpulkan bahwa kompleksitas model yang dispesifikasi dalam penelitian ini mampu menjelaskan 72,00\% varian data yang telah terkoreksi. Begitu pula nilai GFI = 0,990 dan SRMR = 0,087 yang menunjukkan model fit yang baik (GFI > 0,90 dan SRMR mendekati nol).

Berdasarkan kerangka konseptual, maka pengujian model hubungan dan hipotesis dapat dilakukan dengan dua tahapan yaitu: (1) pengujian koefisien jalur pengaruh langsung, dan (2) pengujian koefisisen jalur pengaruh variabel mediasi. Uraian hasil pengujian hubungan antara variabel penelitian sebagai berikut:

Tabel 3. Koefisien Jalur Pengaruh Langsung dan Pengujian Hipotesis

\begin{tabular}{clcccc}
\hline Hipotesis & \multicolumn{1}{c}{ Pengaruh Langsung } & $\begin{array}{c}\text { Koefisien } \\
\text { Jalur }\end{array}$ & $\begin{array}{c}\text { C.R } \\
(\mathbf{u j i} \text { t) }\end{array}$ & \multicolumn{2}{c}{ Kesimpulan } \\
\hline $\mathrm{H}_{1}$ & Green Supply Chain Management Daya saing & 0.692 & $9.80^{*}$ & Sig & Diterima \\
$\mathrm{H}_{2}$ & Green Supply Chain Management Kinerja Perusahaan & 0.582 & $7.90^{*}$ & Sig & Diterima \\
$\mathrm{H}_{3}$ & Daya saing Kinerja Perusahaan & 0.416 & $5.30^{*}$ & Sig & Diterima \\
\hline
\end{tabular}

Keterangan: $\mathrm{CR}^{*}=$ Signifikan pada $\alpha=0,05$

Sumber: Hasil Olahan GSCA

Berdasarkan hasil penelitian, maka pengujian pengaruh langsung dan hipotesis penelitian bertujuan untuk menjawab apakah hipotesis yang diajukan dapat diterima atau ditolak. Hasil pengujian hipotesis pengaruh langsung dapat dijelaskan sebagai berikut:

\section{H1: Green supply chain management berpengaruh signifikan terhadap daya saing}

Berdasarkan hasil analisis data diperoleh bahwa nilai estimasi koefisien jalur pengaruh langsung integrasi supply chain management terhadap daya saing sebesar 0,692 dengan nilai titik kritis (CR) sebesar 9,80* $>\alpha=0,05$. Hasil pengujian dapat membuktikan realitas yang terjadi untuk menerima hipotesis $\left(\mathrm{H}_{1}\right)$ bahwa semakin baik penerapan green supply chain management maka daya saing perusahaan semakin meningkat. Koefisien jalur bertanda positif dapat diartikan hubungan antara green supply chain management terhadap daya saing perusahaan searah. Artinya semakin baik implementasi green supply chain management maka daya saing perusahaan semakin meningkat.

Hasil penelitian ini mendukung pernyataan [17] bahwa desain supply chain, perencanaan, dan keputusan operasi memberikan peranan yang penting dalam menentukan keberhasilan atau kegagalan sebuah organisasi. Selanjutnya mendukung pula konseptual yang menegaskan bahwa dukungan strategi perusahaan terhadap operasional perusahaan melalui supply chain berdampak positif terhadap operasional perusahaan secara keseluruhan, sehingga rantai pasokan di desain untuk mendukung manajemen operasi [18].

Temuan dari penelitian ini mendukung peneliti terdahulu bahwa penerapan green supply chain management berpengaruh secara signifikan terhadap keunggulan bersaing, bahwa penerapan supply chain management pada tingkatan yang lebih tinggi berperan penting meningkatkan keunggulan bersaing perusahaan.

Kemudian menolak Hasil penelitian [19] bahwa Rantai pasokan tidak berpengaruh signifikan terhadap keunggulan bersaing pada perusahaan kecil, karena perusahaan kecil 
mengalami kesulitan dalam kemampuan mengelola rantai pasokan yang berdampak pada risiko biaya yang tinggi dan rendahnya daya tawar antara sesama mitra rantai pasokan.

\section{H2: Green supply chain management berpengaruh signifikan terhadap kinerja perusahaan}

Berdasarkan hasil analisis data diperoleh bahwa nilai estimasi koefisien jalur pengaruh langsung green supply chain management terhadap kinerja perusahaan sebesar 0,582 dengan nilai titik kritis (CR) sebesar 7,90* $>\alpha=0,05$. Hasil pengujian dapat membuktikan realitas yang terjadi untuk menerima hipotesis $\left(\mathrm{H}_{2}\right)$ bahwa semakin baik penerapan green supply chain management maka kinerja perusahaan semakin meningkat. Koefisien jalur bertanda positif dapat diartikan hubungan antara green supply chain management terhadap kinerja perusahaan searah. Artinya semakin baik implementasi green supply chain management maka kinerja perusahaan semakin meningkat.

Hasil penelitian ini mendukung pernyataan yang menyatakan bahwa dukungan strategi perusahaan terhadap operasional perusahaan melalui desain supply chain berdampak positif terhadap operasional perusahaan secara keseluruhan, sehingga rantai pasokan di desain untuk mendukung manajemen operasi.

Temuan dari penelitian ini mendukung peneliti terdahulu bahwa praktek Green Supply Chain Management (GSCM) berpengaruh signifikan terhadap kinerja keuangan, kinerja operasional dan kepuasan pelanggan [10,20-23]. Kemudian mendukung pula temuan yang memberikan bukti bahwa GSCM sebagai penggerak utama kinerja operasional perusahaan, bahwa visi strategis GSCM yang sukses dibangun atas dasar kepemimpinan manajemen yang efektif, yang menciptakan dan mengomunikasikan visi strategis GSCM perusahaan.

\section{H3: Daya saing berpengaruh signifikan terhadap kinerja perusahaan}

Hasil pengujian pengaruh langsung daya saing terhadap kinerja operasional diperoleh nilai estimasi koefisien jalur sebesar 0,416 dengan nilai titik kritis (CR) sebesar 5,30*. Hasil pengujian mengindifikasikan bahwa terdapat cukup bukti secara realitas untuk menerima hipotesis $\left(\mathrm{H}_{3}\right)$ yang dinyatakan bahwa daya saing berpengaruh signifikan terhadap kinerja perusahaan. Koefisien jalur bertanda positif dapat diartikan bahwa tingginya daya saing dapat mendukung peningkatan kinerja perusahaan. Dengan demikian semakin tinggi daya saing maka kinerja perusahaan semakin meningkat.

Temuan penelitian ini mampu membuktikan keberadaan teori keunggulan bersaing oleh Porter bahwa persaingan adalah inti dari keberhasilan dan kegagalan perusahaan, serta menentukan ketepatan aktivitas perusahaan yang dapat menyokong kinerja operasional perusahaan. Selain itu temuan penelitian ini konsisten dengan pendapat Gary Hamel dalam [8] menyatakan berdasarkan pendekatan kompetensi, sumber daya saing berasal dari strategi, struktur, kompetensi, inovasi, serta sumber daya yang tangible maupun intangible.

Temuan penelitian ini baik secara deskripsi maupun model pengukuran indikator kualitas produksi sangat prioritas dalam penerapannya menurut penilaian responden dan memiliki kontribusi dominan dalam merefleksikan daya saing perusahaan. Memperkuat pendapat yang dikemukakan [18] bahwa selain berbagai elemen penting dalam operasi, kualitas merupakan kunci kesuksesan perusahaan dalam menjalankan operasionalnya. Selain itu mendukung pendapat bahwa kinerja kualitas yang tinggi sangat penting untuk keberhasilan operasi dan dapat mempengaruhi posisi keunggulan bersaing perusahaan [24].

Model pengukuran daya saing diadopsi dari indikator pengukuran [12,19,25]. Hasil wawancara dengan responden menyatakan bahwa fleksibilitas perusahaan dan mitra bisnis khususnya pemasok dalam pemenuhan kebutuhan pasokan dapat meningkatkan kemampuan perusahaan dalam melayani permintaan dan selera konsumen yang beragam, 
sehingga terjadi penurunan pada biaya, stock outs, dan lead time. Di samping itu kinerja operasional perusahaan dapat selalu tercapai sesuai dengan target yang telah direncanakan oleh pihak manajemen perusahaan. Kesimpulan yang dapat dirumuskan bahwa daya saing membawa manfaat pada peningkatan kinerja perusahaan.

Hasil penelitian ini konsisten dengan temuan beberapa peneliti terdahulu [10,19,2628] bahwa daya saing yang tinggi secara langsung dapat meningkatkan kinerja operasional perusahaan.

\section{H4: Green supply chain management berpengaruh signifikan terhadap kinerja operasional, di mediasi oleh daya saing.}

Tabel 4. Koefisien Jalur Pengaruh Tidak Langsung

\begin{tabular}{lccc}
\hline Path Coefficients & & & \\
\hline & Estimate & SE & CR \\
\hline Green SCM (X1)->Kinerja Perusahaan (Y2) & 0.871 & 0.037 & $23.3^{*}$ \\
\hline
\end{tabular}

Pengujian pengaruh mediasi bertujuan mendeteksi kedudukan variabel intervening dalam model. Pengujian mediasi dilakukan guna menentukan sifat hubungan antara variabel baik sebagai variabel mediasi sempurna (complete mediation), mediasi sebagian (partial mediation) dan bukan variabel mediasi. Pendekatan GSCA pengujian variabel mediasi dapat dilakukan melalui perbedaan koefisien. Pendekatan perbedaan koefisien menggunakan metode pemeriksaan dengan melakukan analisis tanpa melibatkan variabel mediasi.

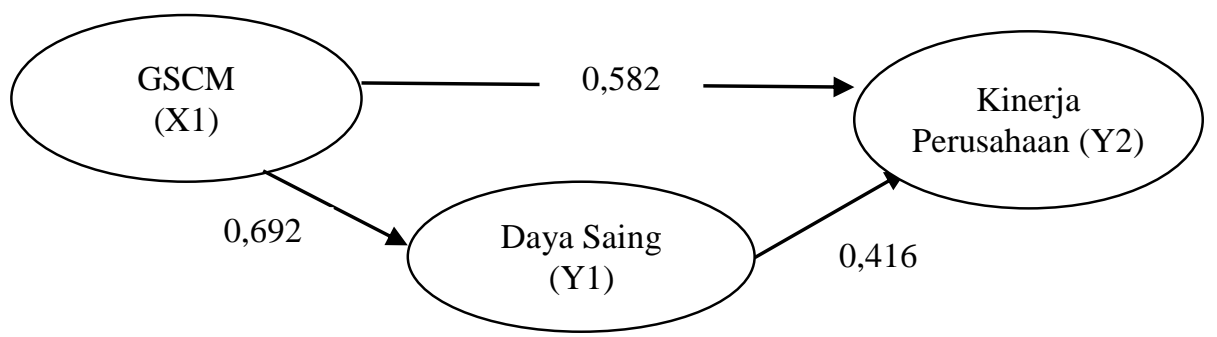

Gambar 2. Struktural Model melibatkan variabel mediasi

Pada Gambar 2 Hasil pengujian pengaruh variabel green supply chain management terhadap kinerja perusahaan pada model awal dengan melibatkan variabel mediasi menunjukkan green supply chain management secara langsung berpengaruh signifikan terhadap daya saing sebesar 0,692 atau sebesar 69,2\% maupun pada variabel kinerja perusahaan sebesar 0,582 atau sebesar $58,2 \%$. Kemudian variabel daya saing juga berpengaruh signifikan terhadap kinerja perusahaan sebesar 0,416 atau sebesar 41,6\%. Agar menyimpulkan dugaan atas variabel mediasi, maka variabel integrasi supply chain management dianalisis kembali hubungannya dengan kinerja perusahaan tanpa melibatkan variabel mediasi.

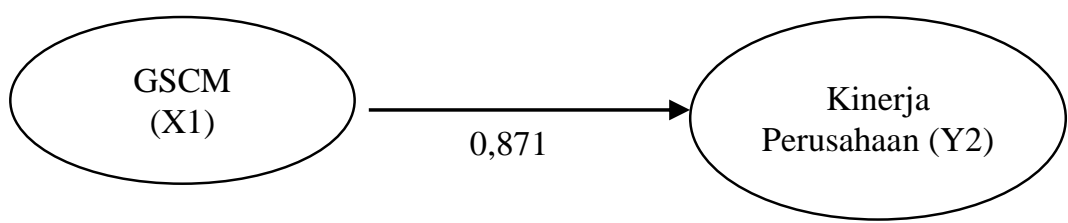

Gambar 3. Struktural Model tidak melibatkan variabel mediasi Sumber: Hasil Olahan GSCA 
Gambar 3 dapat dilihat bahwa nilai koefisien jalur dan signifikan hubungan langsung tanpa mediasi daya saing sebesar 0,871 atau sebesar $87,1 \%$ sehingga sifat mediasi pengaruh green supply chain management terhadap kinerja perusahaan melalui daya saing perusahaan adalah mediasi parsial (parsial mediation). Hasil ini berarti hubungan antara green supply chain management dapat mempengaruhi kinerja perusahaan juga dapat melalui daya saing perusahaan. Upaya yang perlu dilakukan perusahaan agar dapat merancang efesiensi green supply chain dengan menerapkan sistem e-supply chain dimana proses pemesanan bahan baku maka dapat memperbaiki proses pemesanan bahan baku menjadi lebih efektif dan efesien karena adanya integrasi antara semua departemen yang terkait sehingga dapat menciptakan kinerja perusahaan lebih baik [29].

Berdasarkan hasil penelitian dan wawancara pada perusahaan manufaktur di Kota Makassar masih banyak mengalami kendala dalam mengimplementasikan green supply chain management bahkan masih ada yang belum menerapkan, hal ini disebabkan beberapa kendala yang dihadapi, seperti: pedoman baku pelaksanaan green supply masih kurang, biaya pembelian bahan baku hijau mahal, komitmen supplier masih kurang, dan komitmen manajemen puncak masih kurang. Maka dari itu, rekomendasi buat perusahaan dapat dilakukann pada beberapa aspek, yaitu: membangun komitmen bersama antara pemasok, perusahaan dan pemerintah dalam hal penerapan green supply chain mulai dari pembelian hijau, produksi ramah lingkungan sampai pendistribusian hijau.

\section{KESIMPULAN}

Berdasarkan hasil pembahasan dan temuan penelitian, dapat dikemukakan beberapa kesimpulan sebagai berikut:

1). Green supply chain management berpengaruh signifikan terhadap daya saing perusahaan. Hal ini membuktikan bahwa implementasi GSCM pada industri manufaktur di Makassar telah berjalan dengan baik walaupun belum maksimal sehingga tingkat daya saing masih tergolong sedang. Sehingga diharap ada keseriusan manajer dan perbaikan dalam mengimplementasikan proses produksi dan penggunaan bahan baku yang ramah lingkungan.

2). Green supply chain management berpengaruh signifikan terhadap kinerja perusahaan, terbukti semakin baik green Supply chain management semakin baik pula meningkatkan kinerja perusahaan. Hasil ini mengindikasikan bahwa semakin baik interaksi yang dilakukan oleh perusahaan dengan pemasok dan pelanggan dalam menetapkan standar pengiriman dan respon terhadap pelanggan mampu meningkatkan efesiensi biaya sebagai wujud dari kinerja operasional.

3). Daya saing berpengaruh signifikan terhadap kinerja perusahaan. Terbukti bahwa semakin kuat daya saing perusahaan maka semakin baik pula peningkatkan kinerja operasional perusahaan. Hasil penelitian ini menunjukkan bahwa daya saing yang di wujudkan pada kemampuan perusahaan untuk melakukan kualitas produk yang tinggi secara langsung mempengaruhi kemampuan perusahaan.

4). Green supply chain management berpengaruh signifikan terhadap kinerja perusahaan, dimediasi daya saing perusahaan, daya saing bertindak selaku pemediasi sebahagian (partial mediation) dalam menjelaskan pengaruh green supply chain management terhadap kinerja perusahaan, bahwa secara langsung daya saing perusahaan yang tinggi dipengaruhi oleh green supply chain management yang baik dan juga secara langsung daya saing mempengaruhi kinerja operasional perusahaan yang tinggi.

5). Hasil penelitian ini tidak luput dari keterbatasan saat penelitian, sehingga keterbatasan ini dapat disempurnakan pada peneliti selanjutnya. Beberapa keterbatasan tersebut antara lain: responden penelitian fokus pada tingkatan manajer yang kesibukannya 
padat sehingga informasi saat deep interview terbatas, diharapkan peneliti selanjunya memperluas responden penelitiannya.

\section{DAFTAR PUSTAKA}

[1] S. Bahri and F. A. Cahyani, "Pengaruh Kinerja Lingkungan Terhadap Corporate Financial dengan Corporate Social Responsibility sebagai Variabel Intervening," J. Ekon. Univ. Kadiri, vol. 1, pp. 117-142, 2016.

[2] A. K. Garside and H. Y. Asjari, "Simulasi Ketersediaan Beras di Jawa Timur," J. Ilm. Tek. Ind., vol. 14, no. 1, pp. 47-58, 2015.

[3] D. Surjasa, Ahmad, and E. Irawati, "Pengukuran Kinerja Supply Chain CV. X Berdasarkan Lima Proses Inti Model Supply Chain Operations Reference (SCOR)," J. Ilm. Tek. Ind., vol. 5, no. 1, pp. 28-35, 2017, doi: 10.24912/jitiuntar.v5i1.1774.

[4] N. A. A. Seman, N. Zakuan, A. Jusoh, and M. S. M. Arif, "Green Supply Chain Management: A Review and Research Direction," Int. J. Manag. Value Supply Chain., vol. 3, no. 1, pp. 1-18, 2012, doi: 10.5121/ijmvsc.2012.3101.

[5] K. G.P., "Performance measurement systems for green supply chains using modified balanced score card and analytical hierarchical process," Sci. Res. Essays, vol. 7, no. 36, pp. 3149-3161, 2012, doi: 10.5897/sre11.1655.

[6] L. K. Toke, R. C. Gupta, and M. Dandekar, "Green Supply Chain Management; Critical Research and Practices," Proc. 2010 Int. Conf. Ind. Eng. Oper. Manag. Dhaka, Bangladesh, no. November, pp. 9-10, 2010.

[7] C. Ninlawan, P. Seksan, K. Tossapol, and W. Pilada, "The Implementation of Green Supply Practices Chain Management in Electronics Industry," Proceeding Int. MultiConference Eng. Comput. Sci., vol. 3, pp. 17-19, 2010, doi: $10.1108 / 14635771111180725$.

[8] E. Jumady, N. Brasit, Jusni, and M. Pono, "The Effects of Integrative Supply Chain Management on the Just in Time and Competitiveness of the Food and Beverage Manufacturing Companies in Makassar," Sci. Res. J., vol. IV, no. IV, pp. 25-29, 2016.

[9] S. Li, B. Ragu-Nathan, T. S. Ragu-Nathan, and S. Subba Rao, "The impact of supply chain management practices on competitive advantage and organizational performance," Omega, vol. 34, no. 2, pp. 107-124, 2006, doi: 10.1016/j.omega.2004.08.002.

[10] C. Gimenez and E. Ventura, "Logistics-production, logistics-marketing and external integration," Int. J. Oper. Prod. Manag., vol. 25, no. 1, pp. 20-38, 2005, doi: 10.1108/01443570510572222.

[11] M. Munizu, "Critical Total Quality Management in Manufacturing Companies: a Case Study in Makassar," J. Econ. Business, Account. | Ventur., vol. 14, no. 2, 2015, doi: 10.14414/jebav.v14i2.6.

[12] T. Chi, P. P. D. Kilduff, and V. B. Gargeya, "Alignment between business environment characteristics, competitive priorities, supply chain structures, and firm business performance," Int. J. Product. Perform. Manag., vol. 58, no. 7, pp. 645-669, 2009, doi: 10.1108/17410400910989467.

[13] S. Li, S. S. Rao, T. S. Ragu-Nathan, and B. Ragu-Nathan, "Development and validation of a measurement instrument for studying supply chain management practices," J. Oper. Manag., vol. 23, no. 6, pp. 618-641, 2005, doi: 10.1016/j.jom.2005.01.002.

[14] Sugiono, Metode penelitian Kuantitatif Kualitatif dan R\&D. CV. Alfabeta Bandung, 2010.

[15] H. Hwang, "Regularized generalized structured component analysis," Psychometrika, vol. 74, no. 3, pp. 517-530, 2009, doi: 10.1007/S11336-009-9119-Y. 
[16] Solimun, Penguatan Confirmatory Reseach Pemodelan Persamaan Struktural Generalized Structured Componeny Analysis GSCA. Program Studi Statistika FMIPA Universitas Brawijaya. Malang, 2012.

[17] P. Chopra, S. and Meindl, Supply Chain Management. Prentice Hall, 2001.

[18] J. Heizer, B. Render, and C. Munson, Principles of operations management: sustainability and supply chain management. 2016.

[19] S. W. Kim, "Effects of supply chain management practices, integration and competition capability on performance," Supply Chain Manag., vol. 11, no. 3, pp. 241-248, 2006, doi: 10.1108/13598540610662149.

[20] C. S. Ou, F. C. Liu, Y. C. Hung, and D. C. Yen, "A structural model of supply chain management on firm performance," Int. J. Oper. Prod. Manag., vol. 30, no. 5, pp. 526-545, 2010, doi: 10.1108/01443571011039614.

[21] C. S. Yang, C. S. Lu, J. J. Haider, and P. B. Marlow, "The effect of green supply chain management on green performance and firm competitiveness in the context of container shipping in Taiwan," Transp. Res. Part E Logist. Transp. Rev., vol. 55, pp. 55-73, Aug. 2013, doi: 10.1016/j.tre.2013.03.005.

[22] S. Boon-itt and C. Y. Wong, "The moderating effects of technological and demand uncertainties on the relationship between supply chain integration and customer delivery performance," Int. J. Phys. Distrib. Logist. Manag., vol. 41, no. 3, pp. 253276, 2011, doi: 10.1108/09600031111123787.

[23] A. Rohdayatin, P. Sugito, and K. Handayani, "Green Supply Chain: Studi Keterkaitannya dengan Kinerja Lingkungan dan Kinerja Finansial,” J. Manaj. Dan Kewirausahaan, vol. 6, no. 2, pp. 103-114, 2019, doi: 10.26905/jmdk.v6i2.2513.

[24] M. K. Krajewski, L. J., Ritzman, L. P., and Malhotra, Operations Management: Process and Supply Chains, 9th ed. Pearson, 2010.

[25] D. X. Peng, R. G. Schroeder, and R. Shah, "Competitive priorities, plant improvement and innovation capabilities, and operational performance: A test of two forms of fit," Int. J. Oper. Prod. Manag., vol. 31, no. 5, pp. 484-510, 2011, doi: $10.1108 / 01443571111126292$.

[26] S. W. Kim, "The effect of supply chain integration on the alignment between corporate competitive capability and supply chain operational capability," Int. J. Oper. Prod. Manag., vol. 26, no. 10, pp. 1084-1107, 2006, doi: 10.1108/01443570610691085.

[27] R. Rajaguru and M. Jekanyika Matanda, "Influence of inter-organisational integration on business performance," J. Enterp. Inf. Manag., vol. 22, no. 4, pp. 456-467, 2009, doi: 10.1108/17410390910975059.

[28] R. G. Richey, H. Chen, R. Upreti, S. E. Fawcett, and F. G. Adams, "The moderating role of barriers on the relationship between drivers to supply chain integration and firm performance," Int. J. Phys. Distrib. Logist. Manag., vol. 39, no. 10, pp. 826-840, 2009, doi: 10.1108/09600030911011432.

[29] C. O. Doaly, Ahmad, and E. Tanuwijaya, "Perancangan Aplikasi Sistem EPurchasing Dengan Pendekatan Konsep Value Matrix Pada Proses Pemesanan Bahan Baku Perusahaan Springbed," J. Ilm. Tek. Ind., vol. 7, no. 3, pp. 169-180, 2019, doi: 10.24912/jitiuntar.v7i3.6336. 